\title{
The Accouchement of Queen Jane Seymour.
}

\author{
By S. D. Clippingdale, M.D. (Aberdeen), F.R.C.S. (Eng.).
}

\section{(I) Historic note upon Casarian Section.}

CASSARIAN section, in this country, prior to the introduction of antiseptic surgery, seems to have been peculiarly fatal to the mother. Ramsbotham, ${ }^{1}$ writing in 1841 , states that he was acquainted with only thirty cases of the operation, and that in only three of these had the mother recovered. Abroad, the operation seems to have been attended with greater success.

The operation is an ancient one. Pliny ${ }^{2}$ mentions it, and says Scipio Africanus (B.c. 237) was born in this way. As is well known, the procedure takes its name from the fact that Julius Cæsar is reputed to have been born in this manner. If this was so, Cæasar's mother must have survived the operation, for she was living when her son invaded Britain (B.C. 55).

The earliest medical writer upon Cæsarian section was Guy de Cauliac, ${ }^{3}$ who, however, only advocated the operation for the purpose of delivering a living child from a dead mother. De Cauliac published his work in 1363 . In 1581 Russett wrote advocating the operation during the mother's lifetime. Russett's work seems to have given a considerable stimulus to the operation which was soon practised with considerable success in many parts of the Continent. Instances are recorded in which the operation was practised more than once upon the same woman, the most remarkable case of this kind being, perhaps, that in which a surgeon of Bruges delivered his own wife by this method no fewer than seven times. ${ }^{5}$

Among the traditional cases it may be mentioned that Esculapius, the God of Physic is said to have been thus born (Ovid), and, according to Shakespeare, Macduff was "from his mother's womb untimely ripp'd."6

(2) The Case of Queen Jane.

Henry VIII at the time he married Lady Jane Seymour had had but two Queens-Katharine of Arragon, who had borne the Princess (afterwards Queen) Mary, and Anne Boleyn, who had 
borne the Princess (afterwards Queen) Elizabeth. Neither Queen had borne a son to live.

Lady Jane Seymour was a woman of noble parentage and of ancient lineage. Her father, Sir John Seymour, in attendance upon the King when he visited Francis I in France, and when he received the Emperor Charles $\mathrm{V}$ in this country, was descended from the ancient Lords of St. Maur in Normandy. Her mother was a daughter of Sir IIenry Wentworth, of Nettlestead, Suffolk. Of this union, Lady Jane was the eldest of eight children. The King, to celebrate his marriage with Lady Jane (her father dying shortly after it) conferred peerages upon her two brothers then living; the elder became Viscount Beauchamp, and the younger Baron Seymour of Sudeley.

Lady Jane Seymour entered the service of Queen Anne Boleyn as Maid of Honour, but at what time is not known. Seeing, however, that the unfortunate Queen Anne had a reign of only three years it could not have been long either after her coronation or before her death. It was, however, sufficiently long for the King to be attracted by her. The King always took a special interest in the Maids of Honour of his Queens, so that it is not surprising to learn that during Queen Anne's lifetime he sent Tady Jane Seymour, then residing at Greenwich, a purse of sovereigns with a note containing amorous proposals. I ady Jane returned the letter unopened together with the purse, accompanied by a message that " her honour was her fortune." The attention which the King paid the Maid of Honour much distressed the Queen, and is said to have caused a miscarriage in January 1536 .

The King beheaded the Queen May 19, I536, and, without spending unnecessary time in unavailing reflection, straightway married Lady Jane, married her in fact on the following day. For the festivities of this marriage, the cakes must have been baking, as pointed out by Miss Strickland, the previous day.

The age of Lady Jane when she married the King is not exactly known. Authorities agree that she was about twenty-eight. She must therefore have been approaching her thirtieth year when, seventeen months later, her confinement occurred. This momentous event took place near midnight on Friday, October 12, 1537, at Hampton Court Palace. That she did not become encienle soon after marriage is proved by the fact that when, in July 1536 , the question was raised in Parliament as to the succession, answer was returned that the matter might be allowed to stand over as there was no prospect of the Qucen becoming a mother.

The question as to whether Queen Jane was delivered by the Cxsarian section will probably never be definitely settled. Material evidence would depend upon the date of her death. If this had 
taken place a day or two after her accouchément, Casarian section would probably be indicated, but if denth did not occur for twelve days some other cause needed finding. The youthful King Edward himself, in the diary which he kept, informs us that his mother died a "few days" after his birth, and Sanders, the priest, in his De Origince et Progressus Schismatici Anglicance (1585) states that the Queen's death took place upon the second day. This mistake, for such it undoubtedly is, has been reproduced by other writers, and even occurs in the current issue of Burke's Peerage; concerning which the writer addressed a letter to the Editor, and received the following reply, admitting the error :--...

"On reference to the records of IIeralds College, 1 find that "Jane Seymour, third Queen of Henry VIII, died on the " 24th October, 1537, and was buried on the 14th November. "This is good evidence as the funeral arrangements were in " the hands of the IJeralds. Thanking you for drawing my " attention to the point,

$$
\begin{aligned}
& \text { "Believe me, } \\
& \text { "Yours faithfully, } \\
& \text { "Ashworth P. Burke, Editor." }
\end{aligned}
$$

Details of the confinement, scanty though they are, are given by Miss Strickland and in the Dict. Nat. Biog. In accordance with the Court etiquette of the time, Queen Jane had to keep her room for a month before the date of her expected confinement. This deprivation of fresh air and exercise would not conduce to a satisfactory delivery. Fout days after delivery it was necessary for the infant Prince to be taken into the chapel of Hampton Court Palace to be baptised. His mother accompanied him, being carricd upon a litter. The King, who seems to have had a genuine affection for the Queen, sat by her side, holding her hand. There is no evidence that the Queen took special harm by this early removal from her lying-in chamber. That she, however, became seriously ill later seems shown by the fact that the King intended to have gone to Esher, but remained at IIampton on account of the Queen's allered condition. Early upon the day of her death the doctors reported to the l'rivy Council as follows :-

"These shall be to advise your Lordships of the Queen's " estate. Yesterday afternoon she had a natural lax by reason "whereof she began to lighten and (as it appeared) to amend, " and so continued till towards night. All this night she hath " been very sick and doth rather appare than amend. Her "Confessor hath been with Her Grare this morning, and hath" 
" done what to his office appertaineth and even now is prepar-

"ing to Her Grace the Sacrament of unction.

"At Hampton Court this Wednesday morning at eight a clock.

" Your Lordships at Commandment.

" Thomas Cutland. John Chambers, Priest.

"Robert Karhold. William Butts.

" Edward Bayntam. George Owen."

Of the six doctors who sign this certificate, the first three appear to hive been apothecaries, the rest -Chambers, Butts and Owenwere Court Physicians. Chambers was in Holy Orders.

With a view of ascertaining whether the Seymour family possessed any evidence of the alleged Casarian section, the writer applied to the present head of the family, His Grace the Duke of Somerset, and was favoured with the following reply :-

" 35, Grosvenor Square, W.s 30/5/16.

" Dear Sir,---In reply to yours of yesterday, I regret to say

" that though I have Queen Jane Seymour's marriage settle-

"ment, I have no record as to the cause of her death.

"I remain, yours faithfully,

SOMErset."

There appears to be ample authority for the rumour, supported by Miss Strickland, that when the doctors, owing to the protraction of the Queen's labour, explained to the King that an operation (apparently either craniotomy or Casarian section) would be necessary to terminate the labour and requesting His Majesty's direction in the matter, the King replied, "Save the life of the child for another wife can casily be found."*

The period of gestation at which the confinement took place appears to have been normal. The Queen rode horseback across the frozen Thames in January; the announcement of her being with child was made in March, and her confinement took place in October.

Whether the confinement was natural or artificial the Queen was able to write, or dictate and sign, two days later the following letter to the Privy Council :-

" Right truly and well beloved we greet you well and foras" much by the inestimable goodness and grace of Almighty

\footnotetext{
* An exactly opposite reply was made by the Emperor Napoleon (in the case of his consort), who when appealed to hy the doctors replied, "Treat the Empress as you would the wife of a tradesman in the Rue St. Denis. Save both lives if you can. but if you cannot save both lives, save the life of the Empress:"
} 
" God we be delivered and brought in childbed of a PRINCE " conceived in. most lawful Majesty between My Lord the “ King's Majestie and Us. Doubting not but for the Love and “Affection which you bear unto Us and the Commonwealth " of this Realm this Knowledge shall be joyous and glad " tidings unto you, We have thought good to certifie of this " same, to the intent ye might not only under God condign "thanks and praise for so great a benefit but also continually " pray for the long continuance and preservation of the same " here in this life, to the honour of God, joy and pleasure of " my lord the KING and Us and the universal weal, quiet and "tranquility of the whole Realm.

"Given under our Signet at My Lord's Manor of Hampton "Court, the I2th day of October, I 537, "JaNe, QUeEn."

It will be noticed that neither in this letter nor in the doctors' certificate is mention made of any operation. ${ }^{10}$ Nor is any previous incision of the abdomen referred to in the description of the emblaming, ${ }^{11}$ a process rendering necessary an abdominal section with complete evisceration of abdominal contents. Negative evidence as this is, it does not, however, prove that Casarian section was not performed. One frequently hears of major operations being performed with complete success in country places, without the semblance of antiseptic precautions, the atmosphere itself being perfectly aseptic. This may have been the case at Hampton Court where Queen Jane was confined. The Plague was raging in London, but the King issued stringent injunction that no one from the infected City was to approach Hampton Court during the Queen's confinement. ${ }^{12}$ That the Queen did well for at least a week after her delivery is shown by the fact that the King proposed to leave her, but altered his plan when the case took an unfavourable turn a few days before death. What was the cause of this unfavourable turn eight or ten days after a successful delivery? Assuming that Cæsarian section had been performed, may it not have been that the wrappings with which the patient had been swathed, were removed for the first time and then, through want of cleanliness, septic peritonitis induced? The existence of peritoneal effusion is perhaps indicated by the expression in the doctors' report that after a "natural lax" the patient "began to lighten."

While, therefore, it might be rash to assume Casarian section had taken place it might be equally rash to assert the contrary. Rumours concerning exalted personages do not take a firm hold in the public mind without, as a rule, some ground. That the belief in Queen Jane's delivery by the Casarian section was strongly held 
is shown by the ballads writlen at the time, some of which are here reproduced.

(I) From Miss Strickland's "Life of Queen Jane."

"When as King Henry ruled this land, He had a Queen, I understand, Lord Seymour's daughter, fair and bright;

Yet death, by his remorseless power, Did blast the bloom of this fair flower.

O mourn, mourn, mourn, fair ladies, Your Queen, the flower of England's dead.

"The Queen in travail pained sore, Full thirty woeful hours and more, And no ways could relieved be, As all her ladies wished to see. Wherefore the King made greater moan Than ever yet his Grace had done.

"Then being something eased in mind, His eyes a troubled sleep did find, When dreaming he had lost a rose, But which he could not well suppose A ship he had a "Rose" by name, Oh, no, it was his Royal Jane.

"Being thus perplexed with grief and care A lady to him did repair, And said, ' $O$ King, show in thy will The Queen's sweet life to save or spill.'

'Then as she cannot saved be, Oh, save the flower though not the tree.' O, mourn, mourn, mourn, fair ladies, Your flower, the Queen of England's dead."

(2) From “'Notes and Quiries," 2ND Series, XI, 131.

"Oh women, oh women, If women ye be, You'll send for King Henry To come and see me.

" Oh, King Henry, King Henry, If King Henry ye be, You'll send for the doctor

To come and see me. 
" Oh Doctor, oh Doctor,

If Doctor ye be,

You'll open my right side

And save my baby.

" They churched her, they churched her,

They dug her her grave,

They buried her body,

And christened her babe."

N.B.- It will be noticed that in the above rhyme a right-sided laparotomy is indicated.

(3) From " Englisil and Scottish Ballads," by Francis James CHILD.

(Extract): "The surgeon was sent for; he came with all speed, In a gown of black velvet from heel to the head; He gave her rich caudle, but the death sleep slept she, Then her right side he opened and the babe was set free.

"The babe it was christened and put out and nursed, While the Royal Queen Jane lay cold in the dust."

(4) A ScotTish Version (From the Same.).

"Queen Jeanie, Queen Jeanie, travelled six weeks and more Till women and midwives had quite given her o'er.

' $\mathrm{O}$, if ye were women as women should be,

Ye would send for a doctor, a doctor to me.'

"The doctor was called for and set by her bedside,

'What ails thee, my ladie, thine eyes seem so red?'

' $O$ doctor, $O$ doctor, will ye do this for me,

To rip up my two sides and save my babie?'

" But with sighing and sobbing she's fallen in a swoon, Her side it was ripped up and her babie was found.

At this bonnie babe's christening there was mickle joy and mirth,

But bonnie Queen Jeannie lies cold in the earth."

N.B.- It will be noticed that in all these rhymes the Queen showed a strong desire to save her child's life.*

* It need scarcely be said that Hampton Court Palace is haunted by the ghost of Queen Jane. On each anniversary of the Queen's death, at midnight, the apparition, in orthodox style, clad in a shroud, and holding a taper, passes along a corridor and enters the room in which the confinement took place. 


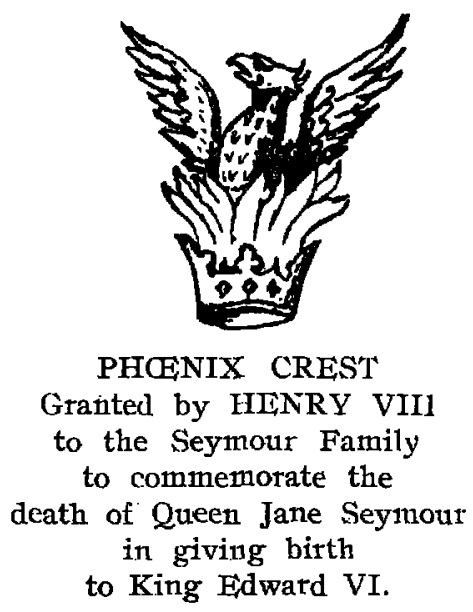

I. Ramsbotham, Francis. "Principles and Practice of Obstetric Medicine and Surgery."

2. Pliny. "Natural History," Book viii., Chap. 9.

3. De Cauliac. "Chirurgia," Paris, $13^{6} 3$.

4. Rusett, lirancois. "Traite Nouveau de l'Hysterotomotokia," Paris, 1581.

5. The fullest history of this operation is perhaps that contained in Cooper's "Surgical Dictionary," 1838 .

6. "Macbeth," Act V., Scene 7.

7. "Dictionary of National Biography."

8. Strickland, Agnes. "ILives of the Queen's of England."

9. Fuller's "Church History." The original is one of the Cottonian MS.

10. 'I'his letter will he found in the Cottonian MS. The date of the Qucen's letter to the Privy Council is erroneously given by Fuller as October 22 (two days before the Queen died). This mistake has been repeated by Ramshotham.

I 1. State Papers. Domestic Series, No. ro6o.

I 2. State Papers. Iomestic Series, No. 893 , 